ANUARIO DE Estudios Medievales

51/1, enero-junio de 2021, pp. 241-268

ISSN 0066-5061

https://doi.org/10.3989/aem.2021.51.1.08

\title{
ISTE LIBER EST DE FERNANDUS EPISCOPUS CORDUBENSIS. LIBROS Y LIBRERÍAS EPISCOPALES PENINSULARES EN EL OTOÑO DE LA EDAD MEDIA (SIGLOS XIII-XV)*
}

\author{
ISTE LIBER EST DE FERNANDUS EPISCOPUS CORDUBENSIS. \\ EPISCOPAL BOOKS AND LIBRARIES IN THE IBERIAN PENINSULA \\ IN THE LATE MIDDLE AGES (13 $3^{\text {th }}-15^{\text {th }}$ CENTURIES)
}

\author{
J. ANTONI IGLESIAS-FONSECA \\ Universitat Autònoma de Barcelona \\ https://orcid.org/0000-0002-0117-9861
}

\begin{abstract}
Resumen: La biblioteca episcopal, en la doble acepción de biblioteca particular de un obispo y de biblioteca institucional, está bien testimoniada para el período bajomedieval (ss. XIII-XV). A partir de documentación diversa (cancillería, eclesiástica, notarial, etc.) y de códices conservados (algunos con exlibris, notas de posesión, emblemas heráldicos y otros indicios), es posible hacer una aproximación a los libros y librerías episcopales peninsulares de ese periodo. Su estudio, en general, se había limitado a la edición y análisis de los documentos que las recogían. En las últimas décadas, en cambio, han proliferado los dedicados al estudio del mecenazgo de un obispo concreto o de un conjunto más amplio (por ejemplo, el patrocinio de obispos catalanes o aragoneses en época bajomedieval). También ha recibido una atención especial el Pontifical, el "libro del obispo", una tipología libraria específica y muy relevante por su factura lujosa.
\end{abstract}

Palabras clave: manuscrito; libro; biblioteca; obispo; patrocinio; Pontifical; iluminación.

Abstract: The episcopal library, in its double definition as a bishop's private library and an institutional library, is well documented during the late medieval period $\left(13^{\text {th }}-15^{\text {th }}\right.$ centuries $)$. Drawing on diverse documents (chancellery, ecclesiastical, notarial, etc.) and preserved codices (some of which include ex-libris, notes of possession, heraldic emblems and other indications), it is possible to consider episcopal books and libraries of the time in the Iberian Peninsula. Until recently, the study of such documents had largely been limited to the editing and analysis of the documents in which they were collected. In recent decades, however, studies on the patronage of bishops, whether individually or in larger groups (as is the case of the patronage of Catalan and Aragonese bishops in late medieval times), have flourished. The Pontifical, the "Bishop's Book", a specific type of book which is very significant because of its luxurious execution, has also received particular scholarly attention.

Keywords: manuscript; book; library; bishop; patronage; Pontifical; illumination.

"El presente trabajo se ha elaborado en el marco de la Red de Excelencia "Cultura escrita medieval hispánica: del manuscrito al soporte digital" (RED2018-102330-T), financiada por el Ministerio de Ciencia, Innovación y Universidades, y es resultado, también, de los proyectos de investigación "Retazos de cultura escrita. Fragmentos y membra disiecta de códices en Cataluña (HUM2007-61471) y "Retazos de cultura escrita. Fragmentos y membra disiecta en la Cataluña central" (FFI2011-29719-C02-02.), financiados por el Ministerio de Ciencia e Innovación y el Ministerio de Educación, respectivamente. Agradezco a las coordinadoras de este monográfico, Dras. María Victoria Herráez y María Dolores Teijeira (ambas de la Univ. de León), como también a Joan Domenge Mesquida (UB), que pensaran en mi persona para este apartado; hago extensivo mi agradecimiento a todas aquellas personas que me han proporcionado materiales esenciales en un momento de pandemia como el presente, con archivos y bibliotecas cerrados. Ellas saben quiénes son y están bien representadas en la bibliografía citada.

Citation / Cómo citar este artículo: Iglesias-Fonseca, J. Antoni (2021), Iste liber est de Fernandus episcopus cordubensis. Libros y librerías episcopales peninsulares en el otoño de la Edad Media (siglos XIII-XV), "Anuario de Estudios Medievales" 51/1, pp. 241-267. https://doi.org/10.3989/aem.2021.51.1.08

Copyright: (C) 2021 CSIC. Este es un artículo de acceso abierto distribuido bajo los términos de la licencia de uso y distribución Creative Commons Reconocimiento 4.0 Internacional (CC BY 4.0). 


\section{SUMARIO}

1. Una biblioteca eclesiástica con perfil propio: la biblioteca episcopal.- 1.1. Una biblioteca episcopal efímera: la de la diócesis de Girona (1325-1512).- 2. Códices y documentos para conocer las bibliotecas episcopales.- 2.1. Una larga tradición de estudio: las bibliotecas episcopales a partir de los documentos.- 2.2. Una línea de investigación innovadora: obispos promotores y coleccionistas de libros iluminados.2.3. El Pontifical, el "libro del obispo".- 3. En conclusión.-4. Bibliografía citada.

\section{UNA BIBLIOTECA ECLESIÁSTICA CON PERFIL PROPIO: LA BIBLIOTECA EPISCOPAL ${ }^{1}$}

Antes de comenzar con nuestro estudio debemos precisar su alcance para evitar malentendidos. No es un estudio de caso, sino una aproximación a las múltiples facetas que ofrece la biblioteca episcopal. El Diccionario de Historia Eclesiástica de España dedica una larga entrada a la voz "bibliotecas eclesiásticas" y empieza definiendo qué debemos entender por "biblioteca" (en el sentido moderno que atribuimos a esta voz: un conjunto de libros, más o menos organizado, reunidos intencionadamente en determinado lugar, para su consulta y uso) y por "eclesiástica" (que quiere decir, como mínimum, que los libros y el lugar donde están reunidos tienen que ver de algún modo con personas o instituciones de carácter eclesiástico, quedando al margen de dicha definición, por tanto, cualquier biblioteca o librería que por su contenido temático pudiese adscribirse a esa expresión pero que no tuviese relación con una persona o institución eclesiástica $)^{2}$. Si adaptamos esta definición a nuestro objeto de estudio, una "biblioteca episcopal" sería el conjunto de libros, más o menos organizado, reunidos intencionadamente en un determinado lugar para su consulta y uso, y que tienen una relación estrecha bien con la institución eclesiástica que los alberga (hablaríamos, por tanto, de una biblioteca episcopal ad hoc, que existiría independientemente del titular de la diócesis), bien con la persona que la define (en este caso, el episcopus u obispo, poseedor de una biblioteca propia, de la que podía disponer libremente y de la que podía beneficiarse, eventualmente, la institución eclesiástica a través de donación,

${ }^{1}$ Abreviaturas utilizadas: $\mathrm{AC}=$ Archivo Capitular; $\mathrm{AD}=$ Archivo Diocesano $; \mathrm{BC}=$ Biblioteca de Catalunya; $\mathrm{BCap}=$ Biblioteca Capitular; $\mathrm{BCC}=$ Biblioteca Capitular y Colombina; $\mathrm{BDH}=$ Biblioteca Digital Hispánica; $\mathrm{BE}=$ Biblioteca Episcopal; $\mathrm{BEV}=$ Biblioteca Pública Episcopal de Vic; $\mathrm{BL}=$ British Library; $\mathrm{BMed}=$ Bibliothèque Mediathèque; $\mathrm{BNE}=$ Biblioteca Nacional de España; $\mathrm{BnF}=$ Bibliothèque nationale de France; $\mathrm{BUB}=$ Biblioteca de la Universitat de Barcelona.

${ }^{2}$ Marín 1972, pp. 250-262. 
préstamo, etc.). Por eso distinguimos entre bibliotecas parroquiales, capitulares, conventuales o monásticas, episcopales o diocesanas, y otras muchas.

Después de un breve recorrido histórico por las bibliotecas eclesiásticas hispánicas desde la época antigua, para la Baja Edad Media el autor de esa definición destaca el importante incremento de los ejemplares en circulación (aun más a partir de la introducción de la imprenta) y la laicización (el crecimiento del patrimonio bibliográfico o librario, del que también hay claras muestras en ámbito eclesiástico, se amplía más allá de estas instituciones, que hasta entonces habían monopolizado la cultura libresca); a este proceso no fueron ajenos la introducción masiva del papel como materia escriptoria, la aparición de los studia generalis o universidades, la paulatina incorporación de copistas profesionales, la institución de la pecia universitaria, así como una mayor alfabetización (que permitía la copia autógrafa de textos, también en lengua vernácula), etc. Estas circunstancias, dependiendo del ámbito geográfico que se estudie, aún apareciendo en ese mismo período histórico, la Baja Edad Media, no se dieron de manera simultánea ni con la misma intensidad. A las bibliotecas eclesiásticas tradicionales (capitulares, monásticas, parroquiales), que no desaparecen, sino que, como hemos dicho, incrementan sus fondos y a las que se les suman nuevas tipologías (como las bibliotecas asociadas a las nuevas órdenes religiosas, muchas de ellas con importantes fondos librarios al final del período estudiado), debemos añadir las bibliotecas universitarias y, en lo que interesa a nuestro propósito, las bibliotecas privadas. Es precisamente a partir del s. XIII y siguientes, en el orden bibliotecal y librario, cuando se produce la gran novedad de

las librerías individuales, o sea, aquellas que tenían que ver, desde cualquier punto de mira, no con organismos o instituciones sino con personas físicas, determinadas y concretas, aunque estuvieran constituidas en cargos públicos y en dignidades.

Un papa, un emperador, un obispo, un mercader, un jurista, toda persona que se tuviera en algo, debía poseer y manejar una colección, mayor o menor, de libros o códices. Así, gran cantidad de personajes o personajillos eclesiales (papas, cardenales, arzobispos, obispos, abades, canónigos, beneficiados y todo tipo de clérigos inferiores) se caracterizan por haber disfrutado de su correspondiente colección libraria. Nace así la biblioteca del obispo como biblioteca privada, propia, independiente de la dignidad eclesiástica que ostenta $^{3}$. En el obispado o diócesis, en la curia episcopal, podía existir, o no,

\footnotetext{
${ }^{3}$ Así, se mencionan expresamente las colecciones de "los arzobispos de Toledo, D. Rodrigo Jiménez de Rada, D. Blas Fernández y D. Pedro Tenorio; el cardenal obispo de Tarazona, Fernando Pérez Calvillo (...); el arzobispo de Sevilla, cardenal Juan de Cervantes; los obispos
} 
una biblioteca. Llegados a este punto es importante recoger la afirmación del autor a propósito de esta última presunción. En puridad, esas colecciones privadas no pueden ser calificadas

de bibliotecas eclesiásticas. La gran mayoría están mucho más vinculadas con la particular personalidad de sus dueños que con sus oficios y dignidades (...). Resulta incuestionable que tales librerías tenían que ver poco o nada con las iglesias o instituciones a que se debían, por el cargo, sus propietarios o poseedores, y que sobre sus libros no gozaban aquéllas de ningún derecho ordinario o eminente. De otro modo, mal se explicaría el fenómeno casi constante de que, en un momento de su vida, tales dueños y coleccionadores disponían de sus fondos bibliográficos, bien para legarlos a sus familiares, bien -y esto era mucho más corriente- a las propias instituciones eclesiásticas con las que estaban ligados. (...)

De hecho, puede observarse que, como no sea por excepción, no aparecen, a lo largo de toda esa Baja Edad Media ni en comienzos de la Moderna, las bibliotecas episcopales o diocesanas propiamente dichas, o sea, las poseídas por los obispos en cuanto tales, formando parte no de sus bienes propios, personales o familiares, sino de los del obispado o diócesis, ubicadas de modo permanente en las casas episcopales y transmitiéndose de obispo a obispo automáticamente. Uno de esos casos excepcionales puede ser la biblioteca episcopal de Gerona en el siglo XIV, sobre la que L. Batlle nos ha dado noticias interesantes ${ }^{4}$.

A partir de lo expuesto, en las páginas que siguen analizaremos las bibliotecas episcopales en la doble acepción comentada: tanto las bibliotecas

García Gudiel, de Burgos; Luis de Acuña, de Segovia; Diego de Anaya, de Salamanca; Lope Rodrigo, de Sigüenza; Fortún Velázquez, de León; Gonzalo Palomeque, de Cuenca (...)”, Ibidem, p. 258. En el texto citaremos los obispados en función de la actividad, el documento o el códice que podamos comentar, ahorrándonos la relación completa de todas las dignidades que haya podido ostentar el titular (Diego de Anaya, por ejemplo, entre 1385 y 1437 fue sucesivamente obispo de Tuy, Orense, Salamanca, Cuenca y finalmente arzobispo de Sevilla).

${ }^{4}$ Ibidem, p. 258. En ese mismo párrafo se ofrecen ejemplos, a partir de algunas de las dignidades mencionadas en la nota anterior, del destino de sus colecciones privadas. Batlle 1947, pp. 136-138, justifica la existencia de dicha biblioteca episcopal medieval. De hecho, el mismo Batlle se cuestiona si en Girona coexistieron dos bibliotecas, una capitular y otra episcopal, o si sería mejor hablar de una única biblioteca. Lo cierto, a tenor de la documentación conservada, es que parece identificarse una biblioteca capitular (desde los orígenes de la catedral, dispersa por diversas estancias de la misma, institucionalizada a partir de 1395) y, diferenciada, una biblioteca episcopal a partir de 1325 (con un inventario datado en 1329, que es el que estudia Batlle 1947). A partir de 1395 comienza un lento proceso de fusión, en torno a la biblioteca capitular, que acabaría en 1512 (año de un nuevo inventario de esta biblioteca capitular que parece reunir, sin distinción alguna, todos los libros de la seo gerundense). Sobre el protagonismo creciente de esta última biblioteca, Batlle 1979 y Perarnau 1983 ofrecen más datos. La de Girona, en suma, habría sido una biblioteca episcopal de "corta" duración. 
propias, privadas, de los obispos, como, de existir, las relacionadas con el obispado (situadas generalmente en la curia episcopal, propiedad de la diócesis y que, entre otras vías, incrementaban sus fondos con las donaciones privadas que podían hacer algunos de los titulares de tales dignidades) ${ }^{5}$.

\section{(1325-1512)}

\subsection{Una biblioteca episcopal efímera: la de la diócesis de Girona}

A partir del último párrafo podemos afirmar, con cierta prevención a falta de un análisis más detallado, que el de Girona parece ser el único caso documentado de una biblioteca episcopal peninsular tardomedieval stricto sensu. Por espacio de casi dos siglos habría existido, diferenciada de la biblioteca capitular, una librería situada en la curia episcopal, con dependencia directa del obispo y que, entre otras vías, incrementaba sus fondos con las donaciones privadas que realizaba tanto el titular de tal dignidad como otros prelados. Esta biblioteca, que estaría instalada en la sede episcopal y pasaría institucionalmente de obispo a obispo (sin dejar de pertenecer en ningún momento a la sede gerundense), se habría fusionado, finalmente, con la biblioteca capitular. No conocemos, para la época estudiada, ningún otro caso documentado de la coexistencia de estos dos entes bibliotecarios, biblioteca capitular y episcopal ${ }^{6}$.

Mención aparte merece una monografía reciente sobre la BEV en conmemoración del 200 aniversario de su fundación. Se afirma, no sin razón, que

en la primera col-lecció de volums de la biblioteca de la catedral (de sant Pere de Vic) cal veure-hi, com és lògic, el precedent de l'actual BPEV creada pel bisbe (Francesc de Veyan i Mola, 1734-1815)․

\footnotetext{
${ }^{5}$ De hecho, si exceptuamos el caso de Girona comentado en la nota anterior, parece no haber existido ninguna biblioteca episcopal medieval según esta segunda acepción. Un ejemplo es el de la actual Biblioteca Episcopal de Barcelona, cuya fundación oficial es de 1775 y cuyos orígenes remotos se sitúan en 1593 (con la Biblioteca del Seminari de Montalegre, anomenat Col-legi del Bisbe, Alarcón 2014). Un análisis detallado de las actuales bibliotecas episcopales o diocesanas revelaría, como en el caso barcelonés, que sus orígenes deben situarse en época moderna (la relación completa en Pons 2019).

${ }^{6}$ El caso más frecuente en época medieval es la existencia de una única biblioteca institucional vinculada a la figura del obispo: la capitular. Para muchas sedes episcopales peninsulares conocemos sus inventarios (algunos muy antiguos, que se remontan a época altomedieval), espacios específicos, donaciones diversas (del obispo, de otros prelados, de canónigos y otras personas relacionadas o no con la seo), bibliotecarios, usuarios, etc. La monografía de Becedas 2007 permite aproximarnos al origen de muchas de ellas para el ámbito de Castilla y León; por nuestra parte, hemos hecho una pequeña aportación a los orígenes de la biblioteca capitular de Barcelona, muy bien documentada, en Iglesias-Fonseca 2020.

${ }^{7}$ La biblioteca se fundó en 1806, y el autor insiste un poco más adelante en esta idea: existe "una estricta continuittat entre la primitiva biblioteca de la catedral i l'actual BPEV, no només
} 
Eso permite al autor retroceder en el tiempo y hablar de fondos manuscritos con siglos de antigüedad, entre los cuales se han identificado códices legados a la biblioteca capitular por alguno de sus obispos. Así se han documentado donaciones de Guillem de Tavertet (1195-1233) 1345) y Jordi d'Ornós (1424-1445) ${ }^{9}$, entre otros. Un códice donado por Galceran Sacosta (Vic, BEV, ms. 132), un bello ejemplar con la obra del canonista Guillermo Durando, es de los más interesantes por tratarse de uno de los pocos casos conocidos de autorepresentación de un miniaturista de época tardomedieval conservado en ámbito peninsular: Iohannes Delcros illuminavit (fig. 1$)^{10}$.

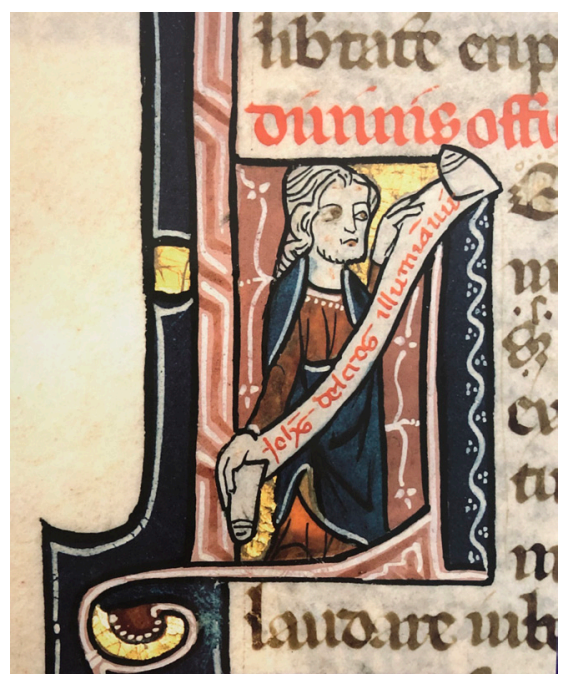

Fig. 1. "Iohannes Delcros illuminavit”. Vic. BEV, ms. 132, f. 92v, año 1331

(C) Biblioteca Pública Episcopal de Vic.

en els espais en què ambdues foren ubicades sinó també en els seus fons bibliogràfics" (Gros 2006, p. 9). A partir de lo expuesto creemos, humildemente y desde el máximo respeto al autor, que es discutible esa identificación entre la antigua biblioteca de la Catedral (la "biblioteca catedralícia" así denominada muchas veces en la monografía) y el concepto "moderno" de Biblioteca Pública Episcopal (es a partir de esa "nueva" realidad que son descritos los códices conservados: "BEV, ms. [número]").

${ }^{8}$ Gros 2003 dedicó un artículo a su biblioteca, objeto del ius spolii papal; Gros 2006, pp. 65-67, reproduce dos de sus códices (BEV, mss. 10, 18).

${ }^{9}$ BEV, ms. 59, un bello ejemplar miniado con obra de San Agustí de Hipona de ca. 11501175 y origen galo (Gros 2006, p. 65).

${ }^{10}$ Es un códice datado en 1331, escrito por un tal Pere Domènech, clérigo, e iluminado por el citado Joan Delcròs (Gudiol 1934, pp. 141-142, reproduce los datos; se hace eco Gros 2006, pp. 78-79; de Sacosta sería también un Misal, Ibidem, pp. 81-82). Orriols 2008, pp. 139-156, elabora una buena síntesis sobre retratos de ilustradores y copistas en códices hispánicos $c a$. 950-ca. 1250. 


\section{CÓDICES Y DOCUMENTOS PARA CONOCER LAS BIBLIOTECAS EPISCOPALES}

Iste liber est de Fernandus episcopus Cordubensis es el exlibris que figura en la hoja de guarda de un Pontifical (Córdoba, AC, ms. 117) conservado en dicha localidad ${ }^{11}$. El tal Fernandus episcopus se ha identificado, después de su análisis codicológico, paleográfico y textual, con Fernando González Daza (o Deza), obispo de dicha ciudad entre 1398-1425. El códice formó parte de su biblioteca (qué mejor prueba que el exlibris en cuestión) y sabemos, por documentación coetánea, que solo un año antes lo donó, junto con otros manuscritos, al cabildo de la seo cordobesa. La nota de posesión, en suma, permite afirmar que González Daza fue el último propietario del manuscrito antes de su ingreso en la biblioteca capitular cordobesa, donde todavía se conserva. Su elaboración, por lo que se desprende de su estudio, no pudo ser una iniciativa llevada a cabo durante su obispado. Se trata de un códice elaborado en Toledo, en la segunda mitad del siglo XIV, que, bien fue adquirido directamente allá y trasladado en fecha incierta a Córdoba, bien fue encargado en origen en un momento anterior a su obispado ${ }^{12}$. El exlibris permite afirmar, con cierta solvencia, que estamos ante un códice que perteneció a su librería particular. Desconocemos, no obstante, las circunstancias de su copia y cuándo lo incorporó González Daza en su biblioteca (lo pudo adquirir en sus tiempos de estudiante, cuando ostentó alguna otra dignidad eclesiástica previa o con motivo de algún viaje a la sede primada toledana siendo ya obispo de Córdoba). Como demostró Gonzálvez Ruiz hace unos años, Toledo se distinguió, desde el siglo XIII, como un importante centro de elaboración de todo tipo de libros litúrgicos ${ }^{13}$. En este caso, es el mismo libro el que, tímidamente, nos da información sobre una biblioteca episcopal, la de González Daza. No es un caso único: como tendremos ocasión de ver más adelante al hablar de la sede de Tarazona, al lado de los exlibris propiamente dichos que podamos conocer, tenemos otros indicios inequívocos de posesión o encargo de códices por parte de obispos y otros prelados (a través de inscripciones en los folios iniciales, de éxplicits, de emblemas heráldicos, etc.).

Junto a las evidencias codicológicas, y complementándolas en muchas ocasiones, tenemos noticias documentales sobre la participación activa de los

${ }^{11}$ García, Cantelar, Nieto 1976, pp. XXVII, 207-208; López-Mayán 2016, pp. 65-70, ofrecen transcripciones divergentes de esta nota. A falta de consultar el original, ofrecemos la del catálogo de 1976.

${ }^{12}$ López-Mayan 2016, p. 70, sugiere que, en este último caso, hubo de ser en los obispados de Fernando Núñez de Cabrera (1346-1350) o de Juan Fernández Pantoja (1379-1397). La paleografía (una gótica textual en el texto, una precortesana cursiva en el exlibris) descarta que podamos identificar el Fernandus episcopus del exlibris con Fernando Núñez de Cabrera.

${ }^{13}$ Gonzálvez 1997, pp. 111, 144-145. 
obispos en multitud de actos que permiten conocer el origen, la formación, crecimiento y dispersión de sus librerías. La documentación puede ser de cancillería, eclesiástica, notarial, etc. El conjunto documental de época medieval conservado para la Corona de Aragón es impresionante (con series de cancillería real, de protocolos notariales o de documentación eclesiástica de todo tipo ininterrumpidas desde el XIII), y ha permitido contar, desde hace décadas, con aportaciones modélicas en el campo de la historia del libro y de las bibliotecas. Algún trabajo clásico, como el impresionante corpus de documentos culturales elaborado por Rubió i Lluch hace más de un siglo, sigue siendo de consulta obligada. Y otros muchos que no podemos recoger aquí ${ }^{14}$. Castilla y León cuentan, a priori, con un conjunto documental un poco más reducido, pero esta circunstancia no ha impedido que también se hayan elaborado trabajos dignos de ser tenidos en cuenta ${ }^{15}$.

La documentación conservada para conocer las bibliotecas episcopales comprende tanto la más explotada tradicionalmente (reflejada en los instrumentos de compra de códices, de encargo de copia, iluminación o encuadernación, de garantía monetaria, de préstamo de libros, testamentos, inventarios y subastas de bienes, por ejemplo), como otra menos conocida pero tan o más interesante que aquélla (cartas, reclamaciones, ius spolii, etc.). Si nos centramos en estos últimos ejemplos, menos conocidos, podemos ver algunos testimonios ilustrativos ${ }^{16}$.

El 26 de noviembre de 1405, el rey Martín el Humano reclamaba por carta a Galceran de Vilanova, obispo de la Seu d'Urgell (sobre el que volveremos más adelante), un ejemplar en tres volúmenes de Nicolás de Lira (¿las Postillae in vetus et novum testamentum, uno de los principales comentarios de la Biblia?). Vilanova parece que fue reacio a la petición real, lo que obligó al rey Martí a exigir a Francesc de Blanes, entonces obispo de Girona (a partir de 1409 lo será de Barcelona), que consiguiese, de la forma que fuese, el códice en cuestión. Desconocemos qué gestiones hizo, pero el 11 de diciembre el rey acusaba su recepción ${ }^{17}$. Pocos años después de esa media-

\footnotetext{
${ }^{14}$ Nos referimos a la magna obra de Rubió 1908-1921; el trabajo póstumo de Trenchs 2011 es también ejemplar sobre el uso de la documentación de Cancillería para este propósito (la introducción de Baiges i Jardí es de lectura obligada). Sobre el estudio del libro y las bibliotecas, así como las fuentes empleadas y sus posibilidades de estudio, contamos para Cataluña con la síntesis de Iglesias-Fonseca 1993 (trabajos hasta 1990); una aplicación práctica del uso intensivo de una de esas fuentes privilegiadas, la notarial, en Iglesias-Fonseca 1996.

${ }^{15}$ Para Castilla y León no conocemos un trabajo equivalente al de Rubió 1908-1921. No obstante, son muchas y muy valiosas las aportaciones sobre el universo del libro en este territorio en forma de artículos, monografías o catálogos de manuscritos. Por señalar algunos relacionados con el ámbito eclesiástico y la cultura del libro (y sin ánimo de exhaustividad): Gonzálvez 1997; Lop 2003; Guijarro 2004, 2018; Beceiro 2007; Jiménez 2020.

${ }^{16}$ De los primeros tipos documentales tendremos ocasión de ver numerosos testimonios a lo largo de la exposición.

${ }^{17}$ Planas 2011a, p. 41, para las referencias bibliográficas y documentales oportunas (otras reclamaciones reales similares en Rubió 1908-1921; Trenchs 2011).
} 
ción, en 1410, el obispo Francesc de Blanes muere y sus bienes fueron objeto del denominado ius spolii papal. Por esta prerrogativa, la Cámara Apostólica vaticana se atribuía el derecho de espolio, esto es, el derecho a apropiarse de los bienes muebles de aquellos eclesiásticos que morían ab intestato, sin testamento válido. Entre el 16 de febrero y el 21 de marzo de ese año sus bienes fueron inventariados, tasados y subastados (excepto los libros, que sí consta documentalmente que fueron tasados, pero no vendidos en subasta $)^{18}$. De hecho, la descripción de los libros permite constatar que Francesc de Blanes poseía algunos códices con las armes del bisbe Joan Ermengol (1398-1408), su antecesor en el cargo. Andando el tiempo, algunos de esos manuscritos se integrarían en la biblioteca capitular barcelonesa y uno de los más célebres es el actual Missal de Santa Eulàlia (Barcelona, AC, ms. 116). Hasta finales del siglo XVI fue conocido con otro nombre, el de Missal del bisbe Ermengol, más explícito sobre su origen ${ }^{19}$. En cualquier caso, la colección de libros de Francesc de Blanes comprende un total de 131 títulos, con ejemplares de temática hagiográfica, litúrgica, jurídica, teológica, histórica y clásicos latinos.

Los obispos, como máximas dignidades eclesiásticas que eran, ejercieron en multitud de ocasiones de asesores, confesores o embajadores reales, compartiendo gustos e intereses artísticos con reyes y alta nobleza (no es casualidad que muchos de esos prelados provengan de ella). Así, es frecuente observar que entre ellos se recomiendan artesanos y artistas (calígrafos, miniaturistas, escultores, orfebres, pintores, etc.), se prestan algunas de sus realizaciones como modelo de copia (por ejemplo, códices con textos raros $\mathrm{o}$, al contrario, muy populares $\mathrm{y}$, por esa razón muy solicitados), se hacen obsequios institucionales y personales, etc. Tenemos multitud de ejemplos ${ }^{20}$. Por citar uno bien conocido, relacionado con la que es, quizás, la biblioteca particular más importante de la primera mitad del XV en Barcelona: la de Bernat d'Esplugues, notario del Consell de la Ciutat de Barcelona. Su muerte en febrero de 1433 llegó a oídos del mismísimo rey Alfonso el Magnánimo, reconocido bibliófilo, quien, sabedor de la impresionante librería del fedatario barcelonés, encargó desde Palermo (Sicilia), y en tres escritos diferentes, ad-

${ }^{18}$ La transcripción del inventario de libros y su estudio en Hernando 2003-2004 (antes, Madurell 1961, pp. 106, 109-110, 112, ofreció otros datos sobre esta biblioteca); para ampliar la información sobre el ius spolii, Williman 1980.

${ }^{19}$ Fàbrega 1977, pp. 14-25, explica el cuándo y el porqué de ese "cambio de nombre" (la razón última estriba en la substitución de la heráldica de sus cubiertas). Más datos sobre la relación entre este archiconocido códice y el obispo Ermengol en Planas 1984, p. 34, n. 8; Hernando 2003-2004, p. 402, ítem 128; Planas 2011a, p. 39, n. 13. Sobre este misal volveremos más adelante.

${ }^{20}$ Los trabajos de Planas 2011a; Escandell 2015; Español 2015 (especialmente este último, como su título indica), ofrecen muchos ejemplos de ese intercambio constante de artífices, objetos e ideas artísticas. 
quirir los millors e pus bells libres (...) de les marmessories del bisbe de Barchinona (Andreu Bertran, obispo de Barcelona, $\dagger$ julio 1433) e d'en Bernat d'Esplugues ${ }^{21}$. Para contextualizar esta petición: entre la muerte de Esplugues, en febrero de 1433, y la subasta de sus bienes (hacia el mes de octubre de ese año), acaeció también la muerte de Andreu Bertran, obispo de Barcelona (1431-1433), algunos de cuyos libros también deseaba el monarca. En dos ocasiones, el 20 y el 30 de septiembre de 1433, el destinatario de las cartas reales y encargado de conseguir los libros fue otro reconocido bibliófilo, Dalmau de Mur, arzobispo de Zaragoza (volveremos sobre él más adelante). Su mediación tenía por objetivo conseguir aquellos bons libres (...) que lo dit Arquebisbe conexerà ésser pertinents al dit Senyor de qualsevol facultat sien (es decir, que el monarca dejaba a su criterio la elección de los mismos, de lo que se deduce que debían compartir gustos e intereses similares). Por lo que sugiere la documentación conservada, no fue esa la única ocasión en que el Magnànim solicitó la mediación de Mur para conseguir un códice que prestigiara la biblioteca que acrecentaba en Nápoles. Entre ambas peticiones, tenemos constancia de otra, datada el 21 de septiembre y con el mismo objetivo; en esta ocasión, el encargado de materializarla era otro prelado, Gonzalo de Híjar, arzobispo de Tarragona. A pesar de los intentos reiterados, el rey parece que no consiguió ninguno de los molts libres notables e de diverses facultats que habían pertenecido al notario barcelonés. Un rey, dos arzobispos, los libros relictos de un obispo y un notario barceloneses, y códices conservados casi 500 años después, nos informan sobre el interés de la monarquía, pero también de altas dignidades de la Iglesia, por bells (y) bons libres.

\subsection{Una larga tradición de estudio: las bibliotecas episcopales a partir de los documentos}

Conocemos más de un centenar de estudios sobre bibliotecas particulares de obispos para el período estudiado que no podemos analizar en detalle por cuestiones de espacio ${ }^{22}$. La documentación, diversa, nos proporciona in-

\footnotetext{
${ }^{21}$ Para una primera aproximación al contenido de la biblioteca de Esplugues, Iglesias-Fonseca 2000, 2001; el apéndice documental que los acompaña da fe del interés del rey por los libros tanto de Bernat d'Esplugues como de Andreu Bertran (además, para el caso de este último, del que desconocemos el paradero de su biblioteca, la solicitud real identifica códices de Tomás de Aquino y Vicent de Beauvais que le habían pertenecido). En Iglesias-Fonseca 2003 e Iglesias-Fonseca, Mayer, Magdalena 2004, puede verse la identificación de algunos códices del inventario de Esplugues con códices conservados actualmente (un hecho insólito si pensamos en la dificultad de esta tarea).

${ }^{22}$ Marín 1972, pp. 250-262, ofrece una primera relación de estudios sobre bibliotecas episcopales. Faulhaber 1987 recoge cerca de 85 ítems bibliográficos (recopilados hasta 1985). Los
} 
formación sobre su contenido (testamentos, inventarios, subastas y memoriales de libros son especialmente útiles). En general, es una imagen estática de la biblioteca: no recoge, ni es su propósito último, todos los libros que un obispo ha podido leer, o adquirir, o copiar de propia mano, en su etapa de formación (como estudiante universitario, por ejemplo) o en momentos posteriores de su periplo vital (en algunos casos, de décadas de mandato tras el paso por obispados sucesivos sin interrupción). Esa imagen fija de la biblioteca gana en dinamismo si la podemos complementar con otros documentos (reclamaciones de libros, préstamos, etc.) y con los códices supervivientes. Por ello la comparación de las bibliotecas episcopales a partir de las fuentes documentales será siempre parcial, porque las mismas fuentes lo son. No obstante, la edición y estudio de esas fuentes, que ocupó sobre todo la segunda mitad del siglo XX, es un paso necesario que aún está por completar ${ }^{23}$.

Si en la segunda mitad del siglo XX se editaron y estudiaron, sobre todo, las bibliotecas o colecciones librarias de los obispos (a través de los códices registrados en fuentes documentales diversas), en las dos primeras décadas de este siglo XXI es loable el esfuerzo que se ha hecho por analizar el estudio del libro iluminado desde el prisma de los promotores y coleccionistas, tanto laicos como religiosos ${ }^{24}$ (entre los cuales, como es de suponer, se identifican multitud de obispos). Además, y de manera complementaria, mientras que en el siglo XX los especialistas en esta materia centraron su interés en la iluminación de biblias altomedievales, los Beatos y las Cantigas, los del siglo XXI han optado por la iluminación de libros en los siglos bajomedievales, de forma que los libros de horas, los libros de coro, los pontificales o, incluso, la cartografia han sido objeto de numerosos trabajos ${ }^{25}$.

En los subapartados que siguen comentaremos tanto la labor del obispado en la promoción y colección del libro iluminado como su papel en la difusión de un libro asociado a la dignidad episcopal, el pontifical. Actividades, además, que son compatibles: hubo obispos promotores y coleccionistas de libros iluminados que encargaron pontificales bellamente decorados y miniados.

35 años transcurridos desde entonces han permitido descubrir nuevas librerías episcopales y nuevas fuentes que permiten reconstruirlas.

${ }^{23}$ Esas aportaciones merecen un estudio independiente. Los repositorios y bases de datos digitales permiten hoy conocer, con unas pocas palabras clave, nuevos ítems bibliográficos: la biblioteca de Ramón Despont, O.P., obispo de Valencia (†1312; Pons 2011) y la de Juan Rodríguez de Villalón, obispo de León (†1424; Suárez 2013), entre las aportaciones recientes. No debemos olvidar, además, que la edición sistemática de corpus documentales sobre libros, lectores y librerías han permitido ampliar las referencias (por ejemplo, los de Hillgarth 1991; Hernando 1995).

${ }^{24}$ Miguélez, Villaseñor 2018, p. 17.

${ }^{25}$ Ibidem, p. 18. 


\subsection{Una línea de investigación innovadora: obispos promotores y coleccionistas de libros iluminados}

En los últimos años han aparecido numerosos trabajos relacionados con este epígrafe. Para la Castilla bajomedieval contamos con trabajos de F. Villaseñor, autor de una obra diversa ${ }^{26}$, y M. López-Mayán ${ }^{27}$, entre otros; para la Corona de Aragón, y por limitarnos a los más recientes, son de consulta obligada los de I. Escandell y J. Planas ${ }^{28}$.

J. Planas presenta ejemplos de la elaboración de códices por iniciativa de diversos obispos catalanes en los siglos finales de la Edad Media (algunos han aparecido ya en este texto): así, Joan Ermengol, obispo de Barcelona (1398-1409), es el prelado que promovió el conocido Missal de Santa Eulàlia (Barcelona, AC, ms. 116) ${ }^{29}$, obra de Destorrents y para el cual conocemos muchos datos documentales; Galceran de Vilanova, obispo de la Seu d'Urgell (Lleida, 1388-1415), promotor de la confección de un bellísimo Misal mixto (Seu d'Urgell, AD, ms. 2048) que donó a la biblioteca de la catedral urgelitana en 1396 (conservamos tanto el manuscrito como el documento original de la donación); Raimon de Castellar, obispo de Girona (1409-1415), a instancias del cual se elaboró un magnífico Pontifical (Girona, AC, ms. 10), tipología libraria sobre la que hablaremos más adelante en detalle; Jerónimo de Ochón, obispo de Elna (1410-1425), bajo cuya iniciativa se elaboraron, entre otros, un Pontifical (hoy en Paris, BnF, ms. 967) y un Misal para uso de la diócesis de Elna (ahora en Perpignan, BMed, ms. 118). Todos tienen en común ser

${ }^{26}$ Baste recordar aquí, entre otras, Villaseñor 2007 (sobre los códices iluminados de Arias Dávila, obispo de Segovia), 2009 (con capítulos como "La iluminación para la Iglesia y su entorno", pp. 139-242, donde aparecen numerosos obispos como mecenas y promotores de códices miniados y el de "La Universidad y los Colegios Mayores", pp. 293-299, referido al Colegio de San Bartolomé de Salamanca y la labor de Diego de Anaya, obispo de Salamanca, ahora revisada también por Jiménez 2020), 2012 (sobre los códices iluminados de este último obispo), 2018 (centrado en la promoción artística de Lope de Barrientos, obispo de Segovia).

${ }^{27}$ Buena parte de los trabajos de López-Mayán se centran en los pontificales, muchos de ellos iniciativa de obispos identificados, y son analizados en el apartado siguiente, al que remitimos para las referencias.

${ }^{28}$ Escandell 2015; Planas 2011a, 2011b, 2016. Reiterar que estos trabajos, como los recogidos en las notas anteriores para la Corona de Castilla, se centran en la relación estrecha del obispado peninsular con la elaboración de códices miniados y, por tanto, no es nuestra intención recoger en este texto las numerosas aportaciones que dichos autores han elaborado sobre otros promotores. En la medida de lo posible ofrecemos las de la última década (2010-2020), entendiendo que incorporan los trabajos anteriores más significativos.

${ }^{29}$ Fàbrega, Bohigas 1977 reproducen tanto los documentos originales sobre su gestación como algunas de las ilustraciones más interesantes. Muchos de los códices que se mencionan a continuación en el texto han merecido la atención de la autora, u otros autores, en artículos específicos que, por razones de espacio, no podemos recoger aquí: remitimos a Planas 2011a, 2011b, 2016 para los mismos. Con el Missal de Santa Eulàlia hacemos una excepción por tratarse de un monumento bibliográfico de la miniatura bajomedieval. 
ejemplares de factura codicológica lujosa, de bella caligrafía, con multitud de ilustraciones y, en algún caso, obra de miniaturistas conocidos (como el catalán Destorrents del Missal de Santa Eulàlia de Barcelona o el picardo Jean de Caudrelies para los dos últimos manuscritos) e influenciados por las principales corrientes y motivos iconográficos europeos de la época (por los contactos de dichos obispos, muchos de ellos consejeros reales y participantes activos en la política religiosa de la época: sus viajes por Europa están perfectamente documentados); además, los códices de Joan Ermengol, de Galcerán de Vilanova y de Jerónimo de Ochón cuentan con un elemento adicional que permite afirmar una participación activa en su elaboración: las armes del bisbe, los emblemas heráldicos que figuran de manera destacada en los mismos. Somos conscientes de que su existencia no es un elemento definitivo de atribución ${ }^{30}$, pero tenemos constancia documental de la participación directa de dichos obispos en su elaboración en muchos casos. Además de las señales heráldicas, en esos y otros ejemplos conocidos, tanto de la Corona de Aragón como de otros territorios, es constante la representación destacada del obispo promotor en alguna de las miniaturas principales del códice.

En la línea desarrollada por J. Planas se inscribe el trabajo de I. Escandell ${ }^{31}$, que amplía la nómina de noticias documentales y códices miniados relacionados con obispos de la Corona de Aragón. Después de una breve introducción sobre la promoción de libros en las sedes episcopales, en un segundo bloque, el que aquí interesa, recopila noticias documentales y manuscritos en los que la presencia de la heráldica y la autorepresentación de los prelados, ya apuntadas en apartados anteriores, muestran su deseo de promoción y posteridad. Los datos que ofrece, tanto de tipo documental como codicológico, son numerosos.

\footnotetext{
${ }^{30}$ En algunos casos se puede aducir, con razón, que la inclusión de un escudo o cualquier otra marca heráldica no permite afirmar con rotundidad que un códice ha sido elaborado a instancia del titular del distintivo. Conocemos multitud de ejemplos en los cuales el emblema puede haber sido incluido en un momento posterior a su adquisición o recepción por vía de una donación; en otros se observa que se ha borrado un emblema anterior, el original, y se ha incorporado el del nuevo propietario. Las circunstancias son diversas. Pero los documentos conservados que recogen la génesis, el proceso de elaboración del códice, su inventario o donación posterior vienen en ayuda de esas marcas heráldicas al incorporar noticias interesantes y definitivas: así, por ejemplo, en el documento de 1396 por el cual Galceran de Vilanova dona a la catedral de la Seu d'Urgell el Missale mixtum recoge que, además de sus 373 "pargameni vitulorum delicatorum scriptum, instoriatum et depictum pluribus instoriis et illuminaturis siue litteris, ac spaciis deauratum, et pluribus coloribus perfusum, contiene inter alia ante calendarium est signum nostrum depictum siue arme in modico scuto ibi figurato". Así es: los emblemas de Vilanova figuran en el espacio indicado.

${ }^{31}$ Escandell 2015. La autora coincide con los datos aportados por Planas 2011a en el caso de algunos obispos de las diócesis catalanas (no todos), aporta muchos otros y amplia de manera importante la lista de prelados de otras diócesis, no catalanas, de la Corona de Aragón.
} 
De los muchos ejemplos aportados por Escandell, dos centrados en el arzobispado de Zaragoza son lo suficientemente elocuentes de la riqueza y las posibilidades de estudio sobre las bibliotecas y los libros que pertenecieron a obispos relacionados con esa demarcación. Uno tiene por epicentro Tarazona. En esa sede episcopal ejercieron los hermanos, y obispos sucesivos en el tiempo, Pedro y Fernando Pérez Calvillo (1352-1391 y 1392-1394, respectivamente), a los cuales se relaciona con un Pontifical que conserva su señal heráldica (hoy en San Marino-California, Huntington Library, HM 1078). La datación del códice casa con esa época, pero en este momento es imposible saber, por carecer de más datos, si debe atribuirse a uno u otro obispo. Lo cierto es que pasó por la biblioteca de uno de ellos. También fue titular del obispado Jorge Bardají Ram (1442-1464), que sería el propietario, según una anotación del folio de guarda, de un Misal Romano conservado, aun hoy, en dicha sede (Tarazona, AC, ms. 123) 32. El sucesor de Bardají fue Pedro Ferriz (14641478), al que se asocia también con un nuevo Misal Romano (Tarazona, AC, ms. 98) ${ }^{33}$ gracias al éxplicit inequívoco y el escudo heráldico que figura en el mismo. Finalmente, Andrés Martínez Ferriz es el obispo siguiente (14781495) y el propietario de un Pontifical (Tarazona, AC, ms. 96) ${ }^{34}$ con noticias interesantísimas: el éxplicit recoge que se trata de un encargo de dicho obispo, que fue acabado en 1489 y donado a dicha sede episcopal en 1493. En el frontispicio del códice (fig. 2) se dan nuevos elementos que permiten asociarlo con Martínez Ferriz: en una inicial historiada se representa un obispo confirmando a un niño (evocación, en un sentido amplio, tanto del promotor como de la dignidad episcopal en general); en la parte central e inferior de la orla que enmarca el folio se distingue, encima del escudo de armas, una mitra (uno de los símbolos del obispo); debajo del emblema heráldico de Martínez Ferriz, que está situado en la parte inferior del folio, una rúbrica del mismo tamaño y color que el incipit del texto refuerza la idea de promoción y autorepresentación con la siguiente inscripción: $R$ (everindissi)mi D(omi)ni Andree Martinez E(pisco)pi Tirasonen(sis). Los pontificales, como tendremos ocasión de ver en el apartado siguiente, son uno de los libros predilectos de los obispos. En este último ejemplo los datos son tan numerosos que es indudable la relación entre el obispo promotor y el códice conservado; en otros casos (por ejemplo, cuando sólo conservamos un emblema heráldico que permite relacionarlo con un

\footnotetext{
32 "Este misal es del obispo (...) de mi Gorge (sic) XXVI dias de mayo seyzo anyo de mil cuatrozentos L anyos" (según transcripción de Falcón 1995, pp. 144-147).

33 "Animam meam Deus in te confido. Explicit. Anno 1471" (Falcón 1995, pp. 125-139, lám. II-III, pp. 444-445); sobre los Ferriz, y el Misal y el Pontifical citado más adelante, véase también Franco 2018, pp. 187-188.

${ }^{34}$ El largo éxplicit en ff. 312v-313r: más datos en Falcón 1995, pp. 117-123, n. 40 y lám. II, p. 444; Falcón 1996 lo estudia detenidamente.
} 
obispo concreto), las circunstancias de elaboración del libro son más difíciles de discernir (puede ser un libro poseído con anterioridad al obispado, incluso de los tiempos de estudiante universitario del prelado o de una dignidad posterior; puede tratarse de una donación o de una adquisición; etc.). Tenemos numerosos ejemplos documentales que responden a una infinidad de casos.

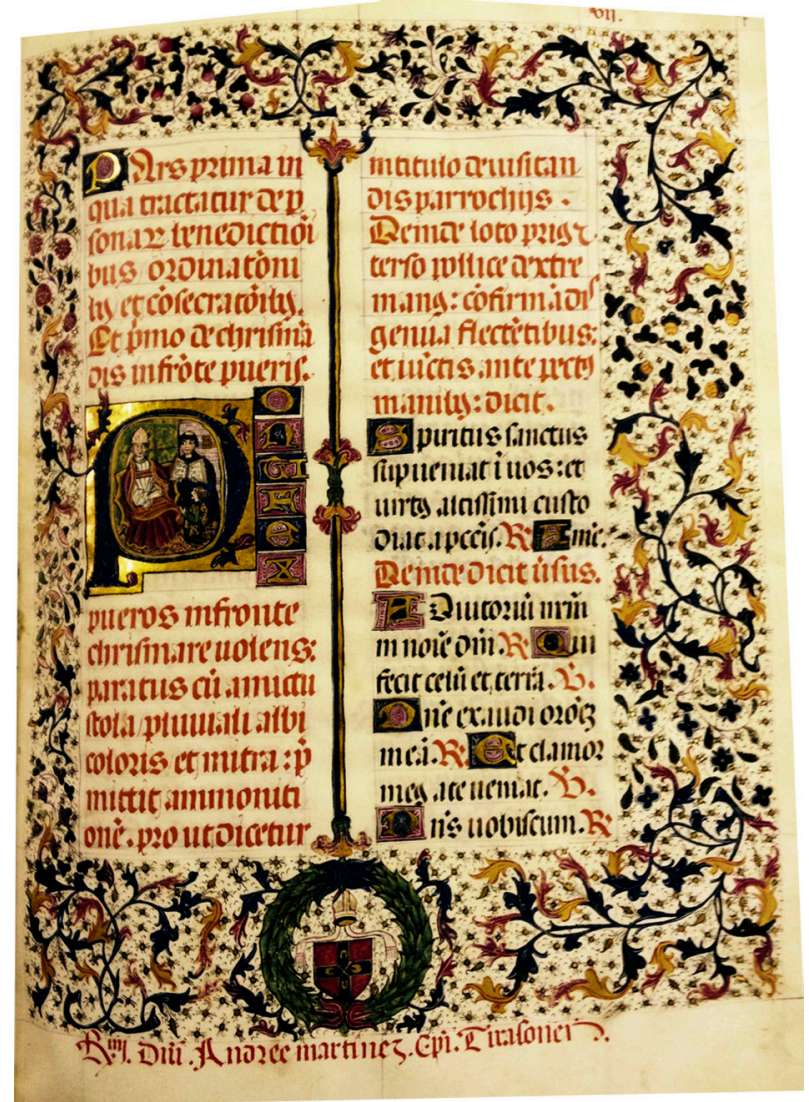

Fig. 2. Pontifical de Andrés Martínez Ferriz, obispo de Tarazona (1478-1495).

Tarazona AC, ms. 96, f. 7r, año 1489 (C) Archivo Capitular de Tarazona.

El segundo ejemplo turiasonense que queremos aportar, aunque sea de manera somera, lo personifica Dalmau de Mur i de Cervellós ${ }^{35}$, ya mencionado

${ }^{35}$ Escandell 2015 ofrece datos sobre la personalidad de este prelado y sus muchas actividades de mecenazgo; Duran, Lacarra 1996, estudiaron el testamento. 
anteriormente. Este prelado catalán fue obispo de Girona (1415-1419), arzobispo de Tarragona (1419-1431) y acabó sus días como arzobispo de Zaragoza (1431-1456). Las noticias documentales y emblemas heráldicos identificados permiten afirmar que dos códices conservados hoy en Valencia (el Policraticus de Juan de Salisbury; Valencia, AC, cód. 50) y en Barcelona (sendos textos de Juan Casiano, el Instituta coenobiorum y el Liber collationum; Barcelona, BC, ms. 657: fig. 3), se incorporaron a su biblioteca siendo arzobispo de Tarragona. Su testamento nos ofrece más noticias sobre su librería y el destino de algunos ejemplares: así, donó a la catedral de Girona una Biblia boloñesa del siglo XIII (Girona, AC, ms. 6) que había pertenecido al papa Benedicto XIII; hizo lo propio con otra Biblia boloñesa, que donó a la catedral de Tarragona (hoy conservada en El Escorial, ms. a. I. 5) y, finalmente, dos Pontificales (uno grande, otro portátil), se habrían quedado en la catedral de Zaragoza (su paradero actual se desconoce). Nótese el destino de los mismos y las dignidades que Dalmau de Mur ostentó en su dilatada vida. A tenor de la calidad de los códices supervivientes, con toda probabilidad esos pocos testimonios son un pálido reflejo de lo que hubo de ser una biblioteca impresionante. Dalmau de Mur es, quizás, el prelado catalán más destacable por las actividades de patrocinio artístico en la Corona de Aragón en época tardomedieval, tanto por la cantidad como por la calidad de lo conservado, pero no es el único ${ }^{36}$. Por las iniciativas llevadas a cabo en el ámbito del libro iluminado es de justicia señalar también a Gastón de Montcada, obispo de Huesca (1323-1328) y de Girona (1328-1334), que fue el promotor de sendos manuscritos conocidos por su nombre: el Breviario de G. de M. (Huesca, AC, ms. 13) y el Pontifical de G. de M. (Girona, AC, ms. 93). Se han hecho, o podrían hacerse, estudios similares sobre el patrocinio artístico de prelados aragoneses, valencianos o castellanos en torno al libro, cuyas iniciativas tuvieron un papel importantísimo en su difusión en el obispado correspondiente (primero en torno al libro manuscrito y más tarde en torno al libro impreso o de molde).

\footnotetext{
${ }^{36}$ Vidal de Canellas, Jaume Sarroca, Fra Ademar, Gastón de Montcada, Pere Clasquerí, Fra Francesc Riquer, Guillem Pons de Fenollet y Francesc Climent son otros prelados con "obra artística" en las diócesis aragonesas en época bajomedieval (Lacarra 1988, 1991).
} 


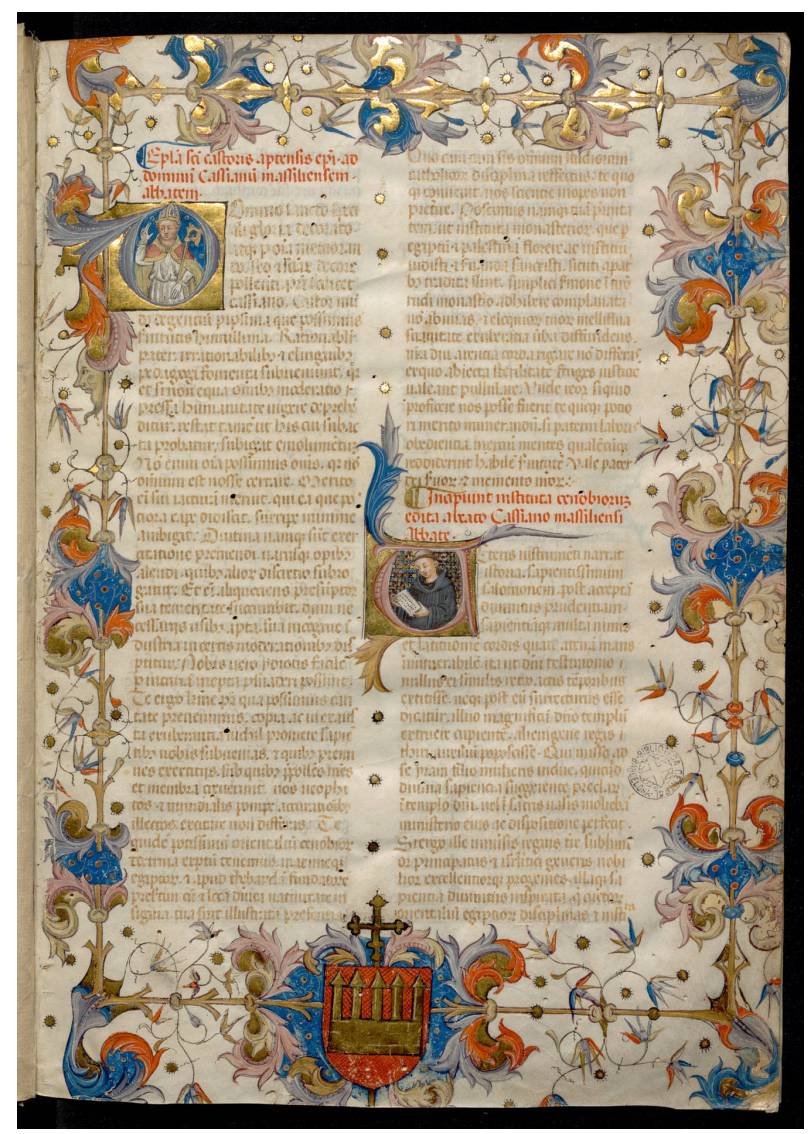

Fig. 3. Casiano, Instituta coenobiorum y Liber collationum.

Propiedad de Dalmau de Mur, arzobispo de Tarragona y Zaragoza (1419-1456). Barcelona, BdC, ms. 657, f. 1r. (C) Barcelona, Biblioteca de Catalunya.

Mención aparte constituye el trabajo de F. Español ${ }^{37}$. Se trata de un análisis exhaustivo del códice BL Ms. Add. 28962, que corresponde a un Salterio y Libro de Horas promovido por el dominico Joan de Casanova, entonces obispo de Elna, destinado a la biblioteca del rey Alfonso el Magnánimo. El códice, bellamente iluminado, sigue el programa iconográfico y textual del dominico, que fue también diplomático y confesor real (y que vería recompensados sus desvelos con la dignidad cardenalicia años más tarde). La elabo-

${ }^{37}$ Español 2002-2003. Lo mencionamos de manera singular por tratarse de un estudio modélico, que se centra en un único códice (otros muchos manuscritos ya mencionados cuentan también con bibliografía que no hemos podido reseñar con detalle). 
ración del manuscrito se dilató en el tiempo (1424-1443, más allá de la vida de su promotor, Casanova, $\uparrow 1436$ ), y es un producto del taller de la familia Crespí de Valencia. Finalmente se integraría en la biblioteca de su destinatario, Alfonso el Magnánimo, reconocido bibliófilo de la época como ya hemos tenido ocasión de ver (no en vano uno de sus emblemas heráldicos, como es sabido, es precisamente un libro abierto como testimonio de su bibliofilia declarada). La autora documenta de manera exhaustiva la elaboración del códice y su programa iconográfico y textual y afirma que, a pesar del destino final, es una idea del dominico Joan de Casanova, que se hace representar, precisamente, en las páginas iniciales del códice al lado del mismísimo rey en actitud de oración ${ }^{38}$. Por tanto, stricto sensu, no sería un códice de una biblioteca episcopal, porque no llegó a integrarse del todo en la de Casanova, pero es un códice elaborado íntegramente desde coordenadas episcopales y que debía haber formado parte de la biblioteca del obispo Casanova. Un análisis detallado de la bibliografía permitiría descubrir situaciones similares a lo largo y ancho de las diócesis de la península en época tardomedieval.

\subsection{El Pontifical, el "libro del obispo"}

Si hay algún libro relacionado de manera estrecha con la dignidad episcopal, como hemos tenido ocasión de apreciar, es el Pontifical, esto es, el libro litúrgico destinado al uso de los obispos. Esta tipología de libros tuvo un desarrollo importante en el período que nos ocupa y cuenta con ejemplares bellamente iluminados que han sido ampliamente estudiados tanto por su valor artístico, contenedores de ricos programas iconográficos consistentes en iniciales historiadas de carácter ritual (...) y miniaturas a plena página, como por su valor simbólico, por tratarse de un vehículo de expresión visual de los intereses ideológicos de la alta jerarquía eclesiástica ${ }^{39}$. No es este el lugar para analizarlos detenidamente: existen estudios tanto de áreas geográficas delimitadas, y para períodos históricos determinados (los pontificales castellano-leoneses de época bajomedieval comentados), como de ejemplares

\footnotetext{
${ }^{38}$ Ibidem, p. 93, fig. 1, que corresponde al f. 14r del códice conservado en la BL (puede verse íntegro en: http://www.bl.uk/manuscripts/ [consulta: 31/05/2020]); de otro parecer es Planas 2014, que cuestiona el papel de Casanova y da un mayor protagonismo al propietario último del manuscrito, Alfonso el Magnánimo.

${ }^{39}$ López-Mayán 2018, p. 275. La autora ofrece una panorámica actualizada del pontifical castellano-leonés de los siglos XII-XV estudiando sus promotores, modelos e influencias. También es de consulta obligada Franco 2018, pp. 151-188, que ofrece una excelente síntesis sobre el medio centenar de pontificales de los ss. XIV-XV conservados en España. El estado de la cuestión más actual sobre el libro iluminado peninsular en Miguélez, Villaseñor 2018, pp. 13-25.
} 
concretos (pontificales propiedad de obispos o cuya elaboración fue iniciativa suya). La relación de trabajos excede los límites de esta presentación. En cualquier caso, determinar el origen concreto de los pontificales conservados (tarea no siempre fácil de hacer en muchas ocasiones), es determinante para poder hacer un análisis de los artesanos que intervinieron, los principales centros de elaboración, los promotores, los motivos iconográficos, los usos litúrgicos, etc. Así, para el reino castellano-leonés, dos son, a tenor de los manuscritos identificados, los principales centros de elaboración de esta tipología libraria: Toledo y, en menor medida, Sevilla (ambas sedes coparían más del $90 \%$ de los códices mientras que Burgos y Ávila son meras comparsas, de las que se conservan ejemplares contados). Especialmente interesante, por lo que respecta a esta presentación, es el papel de los titulares de algunas de las sedes episcopales estudiadas: así, destacan las iniciativas de Alfonso Carrillo de Acuña, arzobispo de Toledo (1466-1482), al que se relaciona con pontificales toledanos bellamente iluminados (el ms. BNE, Vitr. 18-6, ca. 1450-1460, y el ms. Toledo, BCap, ms. 56-24, ca.1470-1480, entre los identificados) $)^{40}$ y de Luis de Acuña, obispo de Burgos (1456-1495), (Burgos, ms. BNE, Vitr. 18-9, ca. 1480) ${ }^{41}$. En ocasiones, el emblema con la mitra y las armas del obispo o del arzobispo en la página inicial no dejan lugar a dudas de esa relación. En todos los casos, estamos ante códices de factura material y formal muy cuidada, de bella caligrafía (siempre encuadrados en las góticas textuales, incluso en los ejemplares elaborados ya casi en el cambio de centuria), decoración exquisita (grandes orlas decoradas con motivos antropomorfos, fitomorfos y zoomorfos, iniciales historiadas y miniaturas a plena página, uso del dorado, etc.) y rematados, en general, con una encuadernación excelente (a tenor de las noticias documentales y los pocos ejemplos conservados). No debemos olvidar el simbolismo del pontifical: se trata del libro del obispo y promovido por él tanto para su uso litúrgico como de demostración de su poder.

A esta práctica autóctona no es ajeno el conocimiento que tenían los prelados castellanos (que podemos hacer extensivo a prelados de otros reinos de la península), de los pontificales aviñoneses, franceses e italianos. Muchos de ellos poseían, por encargo o compra, bellos ejemplares iluminados en esos territorios. Así tenemos, entre los encargos documentados, el ejemplo de Juan de Villacreces, obispo de Calahorra y La Calzada (1382-1394), que también fue canciller de Catalina de Lancaster, esposa de Enrique III (1390-1406),

${ }^{40}$ López-Mayán 2018, pp. 280-281, 286-287, figs. 3, 4; para más información sobre los mismos también puede consultarse López-Mayán 2020. Para los antecedentes inmediatos de los pontificales toledanos, poco conocidos, López-Mayán 2016.

${ }^{41}$ López-Mayán 2018, pp. 281-282, 287, fig. 5. Además, López-Mayán 2012a dedicó a este códice un artículo monográfico. 
que encargó en 1390 en Aviñón un espléndido ejemplar que se conserva hoy en la capital hispalense (Sevilla, BCC, ms. 60-2-48: contiene 110 iniciales historiadas y 31 escenas que elaboró el taller de Jean de Toulouse, miniaturista que trabajaba para la Curia papal de esa ciudad) $)^{42}$. De origen aviñonense es también un segundo testimonio, el pontifical que el papa Luna, Benedicto XIII (1394-1423), encargó hacia 1403 para su sobrino, Pedro de Luna, arzobispo de Toledo (1407-1415), que se conserva todavía en la sede arzobispal (Toledo, BCap, ms. Res. 9) ${ }^{43}$. Los ejemplos de adquisición de pontificales son todavía más numerosos que los encargos. Así, Juan de Cervantes, futuro arzobispo de Sevilla (1448-1453), consiguió en Italia, entre otros volúmenes, un pontifical romano-umbro datado en el siglo XIII, hoy repartido entre Sevilla (BCC, ms. 56-1-11) y Princeton (New Jersey, EEUU) ${ }^{44}$. Su sucesor en la mitra, Alonso de Fonseca, arzobispo de Sevilla (1454-1473), pasará a ser el nuevo propietario del pontifical aviñonense de Juan de Villacreces citado anteriormente ${ }^{45}$.

Conocemos más testimonios de la circulación de pontificales viajeros y su paso por librerías de prelados castellanos que demuestran estrechas relaciones entre ellos (a veces, incluso familiares). Es el caso del ms. Toledo, BCap, 56-19, que recaló en Toledo desde Cambrai tras su paso por Aviñón ${ }^{46}$. El códice, de bella factura, fue elaborado hacia 1270-1275 en Cambrai, probablemente para un obispo (Enguerrand de Créqui, 1273-1285, que encargó las 164 iniciales historiadas y una miniatura a plena página que complementan el texto), y sabemos que fue adquirido en 1408 por Alfonso Carrillo de Albornoz, que en ese momento ostentaba el título de cardenal de San Eustaquio y

\footnotetext{
${ }^{42}$ Aviñón, 1390 (Manzari 2006, pp. 250-252; 2010, pp. 60-61; Franco 2018, pp. 170-174, ofrecen datos sobre este ejemplar). Una síntesis reciente de Aviñón como polo de atracción y mercado librario en tiempos de Benedicto XIII en Escandell 2014-2016.

${ }^{43}$ Elaborado en Aviñón ca. 1403 (Manzari 2006, pp. 162-167; López-Mayán 2014, pp. $52-$ 55; Franco 2018, pp. 174-176).

${ }^{44}$ Mientras en Sevilla se conserva el texto y una única inicial historiada, el de Princeton (University Library, ms. 7) es un volumen facticio compuesto por una veintena de iniciales historiadas que fueron sustraídas del códice sevillano en algún momento del siglo XIX e incorporadas más tarde a la biblioteca estadounidense (Álvarez 1999, p. 102; López-Mayán 2012b, p. 215; Skemer 2013, pp. 163-165).

${ }^{45}$ La hipótesis de López-Mayán 2018, p. 285, por confirmar, pivota en torno al sucesor de Villacreces, Juan Rodríguez de Guzmán, obispo de Calahorra y La Calzada (1394-1403) y, más tarde, de Ávila (1403-1424); años a venir, Alonso de Fonseca será también titular de este obispado (entre 1445 y 1454), inmediatamente antes de ser promovido a arzobispo en Sevilla. El códice habría pasado de Calahorra a Ávila y desde aquí a Sevilla, siguiendo siempre alguno de los titulares de las sedes. De lo que no hay ningún tipo de duda es que se trata del ms. BCC, 60-2-48. Debemos pensar, por tanto, que, en ese momento, se consideraba un bien patrimonial de cada uno de los obispos que lo tuvieron en propiedad, no de un bien episcopal de las sedes por las que pasó. A la muerte de Alonso de Fonseca el pontifical pasó, vía legado testamentario, al fondo del cabildo sevillano y se integraría en su biblioteca, que es donde se conserva aun hoy (Álvarez 1987, pp. 18-19).

${ }^{46}$ López-Mayán 2013 recoge los detalles del trayecto entre Cambrai y Toledo del códice.
} 
estudiaba en el Colegio de San Marcial de Aviñón. Tras su vuelta a la península, donde sería obispo de Sigüenza (1422-1434), el pontifical pasó a su sobrino, Alfonso Carrillo de Acuña, que lo sucederá en el obispado de Sigüenza (1436-1446) y que alcanzará el arzobispado de Toledo (1446-1482). Acuña fue un reconocido bibliófilo y mecenas de las artes y algunos ejemplares de su librería (como el Pontifical Toledo, BCap, ms. 56-19 en cuestión), pasaron a la biblioteca del Cabildo de Toledo. Para el caso castellano-leonés estudiado, se demuestra que códices foráneos (franceses, italianos, flamencos también) y códices autóctonos (de Toledo, Sevilla, Burgos o Ávila), elaborados por encargo o adquiridos en viajes de estudio o misiones episcopales, coexistieron en aparente armonía y adaptados a la realidad litúrgica de cada diócesis. En cualquier caso, todos eran objetos únicos, singulares, y muchos el resultado de un deseo de distinción de su promotor: el arzobispo, cardenal u obispo que sufragó el coste de su adquisición.

\section{EN CONCLUSIÓN}

Hemos tenido ocasión de ver cómo documentos y códices supervivientes informan sobre la gestación, el crecimiento, la dispersión o el destino de las bibliotecas episcopales peninsulares tardomedievales. La identificación de los textos y sus características codicográficas son un indicio, insuficiente en algún caso por la misma naturaleza de las fuentes consultadas, de los gustos e intereses de los prelados. Sea como fuere, la acumulación de datos, indicios y noticias contrastadas son la mejor base para su estudio en profundidad. La información comienza a ser importante. Casi con toda seguridad el interés demostrado en la adquisición, copia o préstamo de libros también debió reflejarse en aspectos poco tratados en esta aportación: entre otros, su uso (privado o público, como es el caso del pontifical, el libro por excelencia del obispo) o los espacios de conservación (que compartiría características con los de otras bibliotecas eclesiásticas, como las capitulares) ${ }^{47}$. Una vez más, tanto documentos coetáneos (que explican dónde se encontraban en el momento de inventariarlos o su destino final, las más de las veces una biblioteca institucional

\footnotetext{
${ }^{47}$ Sobre los "espacios del saber" eclesiástico, y muy especialmente el de las bibliotecas capitulares, se conocen multitud de noticias (es casi inevitable no hablar de ellos cuando se estudia esa institución). En los últimos años se han editado monografías de consulta obligada (Fernández 2008; Campos, et al. 2013; Carrero 2019); en todos los casos, algunas de sus conclusiones pueden ser de aplicación directa a las bibliotecas episcopales (especialmente las referidas a los espacios "mínimos" de conservación o depósito: arcas, armarios, arquibancos, librerías empotradas o portátiles, etc.). Iglesias-Fonseca 2020 habla sobre esos espacios para el caso de la biblioteca capitular de Barcelona en el periodo inmediatamente anterior al aquí estudiado.
} 
relacionada con el difunto), como los mismos manuscritos (con anotaciones textuales sobre su procedencia o signos codicológicos que la explican -exlibris, emblemas heráldicos, etc.-), permitirán profundizar en estos aspectos. Aquí nos hemos limitado a ofrecer una breve aproximación a la cuestión.

\section{BIBLIOGRAFÍA CITADA}

Alarcón i Campdepadrós, Xavier (2014), Història de la Biblioteca Pública Episcopal del Seminari de Barcelona, la més antiga de la ciutat, Barcelona, BPESB.

Álvarez Márquez, María del Carmen (1987), La Biblioteca Capitular de la Catedral Hispalense en el siglo XV, "Archivo Hispalense" 213, pp. 3-68.

Álvarez Márquez, María del Carmen (1999), Manuscritos localizados de Pedro Gómez Barroso y Juan de Cervantes, arzobispo de Sevilla, Alcalá de Henares, Servicio Publicaciones de la Universidad de Alcalá de Henares.

Batlle i Prats, Luis (1947), Inventario de la Biblioteca Episcopal de Gerona $y$ de los bienes propiedad de la Mitra en el año 1329, "Anales del Instituto de Estudios Gerundenses" 2, pp. 133-153.

Batlle i Prats, Luis (1979), La biblioteca de la Catedral de Gerona desde su origen hasta la imprenta, en La cultura a Girona de l'Edat Mitjana al Renaixement, Gerona, Institut d'Estudis Gironins, pp. 87-231.

Becedas González, Margarita (2007), Las bibliotecas históricas de Castilla y León, Valladolid, Consejería de Cultura y Turismo - Junta de Castilla y León.

Beceiro Pita, Isabel (2007), Libros, lectores y bibliotecas en la España medieval, Murcia, Nausícaä.

Campos Sánchez-Bordona, María Dolores; Carrero Santamaría, Eduardo; Suárez González, Ana; Teijeira Pablos, María Dolores (2013), Librerías catedralicias. Un espacio del saber en la Edad Media y Moderna, León - Santiago de Compostela, Universidad de León - Universidade de Santiago de Compostela.

Carrero Santamaría, Eduardo (2019), La catedral habitada. Historia viva de un espacio arquitectónico, Barcelona, Edicions de la Universitat Autònoma de Barcelona.

Duran Gudiol, Antonio; Lacarra Ducay, M. ${ }^{\mathrm{a}}$ Carmen (1996), El testamento de Don Dalmau de Mur y Cervelló, Arzobispo de Zaragoza (14311456), nuevas observaciones, “Aragonia Sacra” 11, pp. 49-62. 
Escandell Proust, Isabel (2014-2016), Benet XIII bibliòfil i el ressó dels llibres d'Avinyó a la Corona d'Aragó, "Lambard. Estudis d'art medieval" 26, pp. 35-56.

Escandell Proust, Isabel (2015), Reflejos de la política episcopal. Manuscritos iluminados y bibliotecas de la Corona de Aragón (s. XIII-XV), "Hortus Artium Medievalium" [en línea] 21, pp. 203-212, DOI:10.1484/J. HAM.5.107389 [consulta: 31/05/2020].

Español Bertran, Francesca (2002-2003), El salterio y libro de horas de Alfonso el Magnánimo y el cardenal Joan de Casanova (British Library, Ms. Add. 28962), "Locus Amoenus" 6, pp. 91-114.

Español Bertran, Francesca (2015), Clientes de calidad y mercado artístico en la Corona de Aragón, en Brouquet, Sophie; García Marsilla, Juan Vicente (eds.), Mercados del lujo, mercados del arte. El gusto de las élites mediterráneas en los siglos XIV y XV, Valencia, Publicacions de l'Universitat de València, pp. 45-76.

Fàbrega Grau, Àngel; Bohigas Balaguer, Pere (1977), El Missal de Santa Eulàlia, Madrid, Edilan.

Falcón Pérez, María Isabel (1995), Estudio artístico de los manuscritos iluminados de la catedral de Tarazona. Análisis y catalogación, Zaragoza, Diputación General de Aragón - Departamento de Educación.

Falcón Pérez, María Isabel (1996), El Pontifical del obispo Andrés Martínez, en el Archivo Capitular de Tarazona: estudio histórico-artístico, en El poder real en la Corona de Aragón (Siglos XIV-XVI). XV Congreso de Historia de la Corona de Aragón (Jaca, 20-25 septiembre 1993), Zaragoza, Departamento de Cultura del Gobierno de Aragón, pp. 403-421.

Faulhaber, Charles B. (1987), Libros y bibliotecas en la España medieval. Una bibliografia de fuentes impresas, Londres, Grant \& Cutler Ltd.

Fernández Fernández, Laura (2008), El libro en la catedral durante la Edad Media: espacio y función, "Lope de Barrientos. Seminario de Cultura" 1, pp. 123-145.

Franco Mata, Ángela (2018), Pontificaux des XIVe et XVe siècles conservés en Espagne, en Berndt, Rainer (ed.), Der Papst und das Buch im Spätmittelalter (1350-1500), Münster, Aschendorff Verlag, pp. 151-188.

García, Antonio; Cantelar, Francisco; Nieto, Manuel (1976), Catálogo de los manuscritos e incunables de la Catedral de Córdoba, Salamanca, Universidad de Salamanca.

Gonzálvez Ruiz, Ramón (1997), Hombres y libros de Toledo, Madrid, Fundación Ramón Areces.

Gros i Pujol, Miquel dels Sants (2003), A propòsit de la biblioteca particular de Guillem de Tavertet, bisbe de Vic, "Arxiu de Textos Catalans Antics" 22, pp. 103-136. 
Gros i Pujol, Miquel dels Sants (2006), La Biblioteca Episcopal de Vic. Un patrimoni bibliogràfic d'onze segles, Vic, Biblioteca Episcopal Patronat d'Estudis Osonencs.

Gudiol, Josep (1934), Catàleg dels Llibres manuscrits anteriors al segle XVIII, Museu Episcopal de Vich, Barcelona, Impremta de la Casa de la Caritat.

Guijarro González, Susana (2004), Maestros, escuelas y libros. El universo cultural de las catedrales en la Castilla medieval, Madrid, Editorial Dykinson - Universidad Carlos III de Madrid.

Guijarro González, Susana (2018), Enseñanzas, saberes y universidades en la Europa medieval, Madrid, Editorial Síntesis.

Hernando Delgado, Josep (1995), Llibres i lectors a la Barcelona del s. XIV, Barcelona, Fundació Noguera.

Hernando Delgado, Josep (2003-2004), El ius spolii papal $i$ llibres d'eclesiàstics. Els llibres en les despulles del bisbe de Barcelona Francesc de Blanes (†1410), "Acta Historia et Archaeologica Mediaevalia" 25, pp. 389-422.

Hillgarth, Jocelyn N. (1991), Readers and Books in Majorca 1229-1550, París, Éditions du Centre national de la recherche scientifique.

Iglesias-Fonseca, J. Antoni (1993), El llibre a la Catalunya baix-medieval. Notes per a un estat de la qüestió, "Faventia" 15/2, pp. 39-73.

Iglesias-Fonseca, J. Antoni (1996), Llibres i lectors a la Barcelona del segle $X V$. Les biblioteques de clergues, juristes, metges $i$ altres ciutadans a través de la documentació notarial (anys 1396-1475) [en línea], Barcelona, Universitat Autònoma de Barcelona, https://www.tdx.cat/ handle/10803/5549 (tesis doctoral) [consulta: 31/05/2020].

Iglesias-Fonseca, J. Antoni (2000), Els clàssics a la biblioteca de Bernat d'Esplugues (†1433), notari $i$ escrivà del Consell de la Ciutat. I, "Faventia" 22/2, pp. 85-119.

Iglesias-Fonseca, J. Antoni (2001), El bibliòfil Bernat d'Esplugues (†1433), notari $i$ escrivà del Consell de la Ciutat, "Barcelona Quaderns d'Història" 5, pp. 57-78.

Iglesias-Fonseca, J. Antoni (2003), Los manuscritos L-35 (Barcelona, AHC), 591 (Barcelona, BU), S.II.26 (El Escorial) y T.II.14 (El Escorial), testimonios de la dispersión de una impresionante librería medieval, la de Bernat d'Esplugues (†1433), notario del Consell de la Ciutat de Barcelona, "Codices Manuscripti. Zeitschrift für Handschriftenkunde" 42-43, pp. 27-53.

Iglesias-Fonseca, J. Antoni (2020), Una catedral de lletres. Llibres, lectors i llibreries a la Catedral de Barcelona (ss. XI-XIII), en Beltrán de Heredia Bercero, Julia (ed.), La Basílica de la Santa Creu i Santa 
Eulàlia: la catedral abans de la catedral. IV Jornades de les Basiliques Històriques de Barcelona (2-3 maig 2019), Barcelona, Ateneu Universitari Sant Pacià - Facultat Antoni Gaudí d'Història, Arqueologia i Arts cristianes, pp. 109-136.

Iglesias-Fonseca, J. Antoni; Mayer, Marc; Magdalena, José Ramón (2004), Notes hebraiques: un element codicogràfic menystingut, en Calders, Tessa (ed.), Actes del I Congrés per a l'estudi dels jueus en territorio de llengua catalana. Barcelona-Girona, 15-17 octubre 2001, Barcelona, Publicacions i Edicions de la Universitat de Barcelona, pp. 273-292.

Jiménez López, Jorge (2020), Libros y primer Humanismo en Salamanca. Inventarios y ámbitos del patrimonio librario del Colegio Mayor de San Bartolomé de la Universidad de Salamanca entre 1433 y 1440, Salamanca, Ediciones de la Universidad de Salamanca.

Lacarra Ducay, M. ${ }^{a}$ Carmen (1988), Mecenatge dels bisbes catalans a les diòcesis aragoneses durant la baixa edat mitjana, "Quaderns d'Estudis Medievals" 14/23-24, pp. 22-32.

Lacarra Ducay, M. ${ }^{a}$ Carmen (1991), Mecenazgo de los prelados zaragozanos durante la Baja Edad Media (1318-1520), en Agudo Romeo, María del Mar (ed.), El espejo de nuestra historia. La diócesis de Zaragoza a través de los siglos. Zaragoza, 5 octubre 1991-6 enero 1992. Catálogo de la exposición, Zaragoza, Arzobispado de Zaragoza, pp. 479-487.

Lop Otín, María José (2003), El Cabildo Catedralicio de Toledo en el siglo $X V$. Aspectos institucionales y sociológicos, Madrid, Fundación Ramón Areces.

López-Mayán, Mercedes (2012a), El pontifical de Luis de Acuña y la iluminación de manuscritos en la Castilla de finales del siglo XV, "Anales de Historia del Arte" 22, pp. 317-331.

López-Mayán, Mercedes (2012b), La producción de manuscritos iluminados en la Curia papal a finales del siglo XIII: dos nuevos pontificales conservados en España, "Archivo Español de Arte" 339, pp. 213-232.

López-Mayán, Mercedes (2013), Más allá de la liturgia: poder y memoria en dos pontificales medievales conservados en España, en Mínguez, Víctor (ed.), Las artes y la arquitectura del poder, Castelló de la Plana, Universitat Jaume I, pp. 2153-2168.

López-Mayán, Mercedes (2014), La producción de manuscritos iluminados en el entorno de la Curia pontificia de Aviñón: un nuevo ejemplar conservado en Sevilla, "Anales de Historia del Arte" 24/extra 2, pp. 45-58.

López-Mayán, Mercedes (2016), À propos de la production de manuscrits liturgiques à Tolède au XIVé siècle: nouveaux témoins, nouvelles ré- 
flexions, en Deuffic, Jean-Luc (dir.), Le manuscrit, entre écriture et texte. Deuxième partie, Turnhout, Brepols Publishers, pp. 55-85.

López-Mayán, Mercedes (2018), Por una historia de la decoración y la ilustración de los pontificales castellano-leoneses (siglos XII-XV): promotores, modelos e influencias, en Miguélez, Alicia; Villaseñor, Fernando (eds.), Medieval Europe in Motion: La circulación de manuscritos iluminados en la Península Ibérica, Madrid, CSIC, pp. 275-288.

López-Mayán (2020), Alfonso Carrillo de Acuña, Archbishop of Toledo (14661482), and the Construction of his Cultural Personality: an Approach from his Liturgical Manuscripts, en Coss, Peter; Dennis, Chris; Julian-Jones, Melissa; Silvestri, Angelo (eds.), Episcopal Power and Personality in Medieval Europe 900-1480, Turnhout, Brepols Publishers, pp. 101-118.

Madurell i Marimon, Jose María (1961), Testamentos e inventarios episcopales, "Analecta Sacra Tarraconensia" 34/1, pp. 103-140.

Manzari, Francesca (2006), La miniatura ad Avignone al tempo dei papi (1310-1410), Módena, Franco Cosimo.

Manzari, Francesca (2010), Committenze di papi, cardinali e vescovi: nuove acquisizioni e considerazioni sulla miniatura avignonese del Trecento, en Planas, Josefina; Sabaté, Flocel (dirs.), Manuscrits il·luminats. L'escenografia del poder durant els segles baixmedievals, Lérida, Pagès Editors, pp. 43-66.

Marín Martínez, Tomás (1972), Bibliotecas eclesiásticas, en Aldea Vaquero, Quintín; Marín Martínez, Tomás; Vives Gatell, José (dirs.), Diccionario de Historia Eclesiástica de España, vol. I (A-C), Madrid, CSIC, pp. 250-262.

Miguélez Cavero, Alicia; Villaseñor Sebastián, Fernando (2018), El estudio del libro iluminado en la Península Ibérica. Estado de la cuestión y nuevas vías de investigación, en Miguélez, Alicia; Villaseñor, Fernando (eds.), Medieval Europe in Motion: La circulación de manuscritos iluminados en la Península Ibérica, Madrid, CSIC, pp. 13-25.

Orriols Alsina, Anna (2018), Recuerdo y salvación. Estrategias visuales para la posteridad en retratos de ilustradores y copistas (c. 950-c. 1250), en Miguélez, Alicia; Villaseñor, Fernando (eds.), Medieval Europe in Motion: La circulación de manuscritos iluminados en la Península Ibérica, Madrid, CSIC, pp. 139-156.

Perarnau Espelt, Josep (1983), La donació de la biblioteca d'Arnau des Colomer i la fundació de la Libraria Sedis de Girona (1397-1411), "Arxiu de Textos Catalans Antics" 2, pp. 171-239.

Planas Badenas, Josefina (1984), El Misal de Santa Eulalia, "Boletín del Museo e Instituto Camón Aznar” 16, pp. 33-62. 
Planas Badenas, Josefina (1998), El esplendor del gótico catalán: la miniatura a comienzos del siglo XV, Lérida, Servei de Publicacions de la Universitat de Lleida.

Planas Badenas, Josefina (2011a), El poder religiós: llibres il-luminats per als bisbes catalans baixmedievals (segles XIV-XV), "Ars Longa: Cuadernos de Arte" 20, pp. 37-48.

Planas Badenas, Josefina (2011b), La ilustración del libro en la Corona de Aragón en tiempos del Compromiso de Caspe: 1396-1420, "Artigrama" 26, pp. 431-478.

Planas Badenas, Josefina (2014), Valence, Naples et les routes artistiques de la Méditerranée: le Psautier-Livre d'Heures d'Alphonse le Magnanime, en Raynaud, Christiane (ed.), Des Heures pour prier. Les Livres d'Heures en Europe méridionale du Moyen-âge à la Renaissance, "Cahiers du Léopard d'Or" 17, pp. 65-102.

Planas Badenas, Josefina (2016), El miniaturista durante el gótico Internacional en Cataluña: formación, trayectoria profesional y prácticas de taller, en Miquel Juan, Matilde (ed.), Ver y crear. Obradores y mercados pictóricos en la España gótica (1350-1500), Madrid, La Ergástula, pp. 63-94.

Pons Alós, Vicente (2011), Ramón Despont, O.P., obispo de Valencia (12911312), "Escritos del Vedat" 41, pp. 225-277.

Pons Alós, Vicente (2019), La biblioteca popular arzobispal valentina, en "No me avergüenzo del Evangelio" (Rom. 1, 16). Homenaje al prof. P. José Manuel Alcácer, O.P., Valencia, Facultad de Teología San Vicente Ferrer, pp. 633-654.

Rubió i Lluch, Antoni (1908-1921), Documents per a la cultura catalana migeval, Barcelona, Institut d'Estudis Catalans.

Skemer, Don C. (dir.) (2013), Medieval and Renaissance Manuscripts in the Princeton University Library, vol. II, Princeton, Princeton University Press, pp. 163-165.

Suárez González, Ana (2013), En torno a los libros de don Juan Rodríguez de Villalón, obispo de León (†1424), "Archivo Ibero-Americano" 73/274, pp. 87-111.

Trenchs Òdena, Josep (2011), Documents de cancelleria i de mestre racional sobre la cultura catalana medieval, Barcelona, Institut d'Estudis Catalans.

Villaseñor Sebastián, Fernando (2007), Los códices iluminados de Arias Dávila: un obispo segoviano en la Corte de Alejandro VI, en Hernando Sánchez, José Carlos (coord.), Roma y España. Un crisol de la cultura europea en la Edad Moderna, Madrid, Sociedad Estatal para la Acción Exterior, pp. 155-171. 
Villaseñor Sebastián, Fernando (2009), El libro iluminado en Castilla durante la segunda mitad del siglo $X V$, Fundación Instituto Castellano y Leonés de la Lengua - Caja Segovia.

Villaseñor Sebastián, Fernando (2012), Los códices iluminados de Diego de Anaya, fundador del Colegio de San Bartolomé en Salamanca, "Goya" 339, pp. 114-129.

Villaseñor Sebastián, Fernando (2018), The Artistic Promotion of Lope de Barrientos, Bishop of Segovia, Avila and Cuenca, en Herráez, M. ${ }^{a}$ Victoria (ed.), Obispos y catedrales. Arte en la Castilla medieval, Berna, Peter Lang, pp. 183-220.

Williman, Daniel (1980), Bibliothèques ecclésiastiques au temps de la papauté d'Avignon. I. Inventaire des bibliothèques et mentions de libres dans les Archives du Vatican (1287-1420). II. Inventaires des prélats et des clercs non français, París, Institut de recherche et d'histoire des textes.

Williman, Daniel; Corsaro, Karen (2003), Early provenances of Latin manuscripts in the Vatican library: Vaticani latini and Borghesiani, Ciudad del Vaticano, Biblioteca Apostolica Vaticana (Studi e Testi, 405).

Fecha de recepción del artículo: julio 2020

Fecha de aceptación y versión final: abril 2021 